\title{
Evaluation of French Bean (Phaseolus vulgaris L.) Genotypes for Growth, Pod Yield and Quality under Sub-Tropical Condition of Garhwal Hills
}

\author{
Hema and D. K. Rana* \\ Department of Horticulture, H.N.B. Garhwal University, \\ Srinagar- 246174, Uttarakhand, India \\ *Corresponding author
}

\begin{abstract}
A B S T R A C T
The present investigation was carried out to study the evaluation of French Bean (Phaseolus vulgaris L.) Genotypes for Growth, Pod Yield and Quality under Sub-tropical Condition of Garhwal Hills at Horticultural Research Centre and Department of Horticulture, H.N.B. Garhwal University, Srinagar Keywords Garhwal, (Uttarakhand), India during summer season, 2017. The experiment was laid out in Randomized Block Design with three replications of 15 genotypes viz., Aishwarya, Anupam, Arka Komal, Durga Pencil Bean, Nirmala 101, Nitara Green, Pant Anupama, Pauri Local, Pencil 66, Rudraprayag Local, Shaguni, Srinagar Local, Somani, Selection-9 and Contender (Check cultivar). During the investigation different growth, yield and quality parameters were recorded. The result of analysis of variance revealed that the mean sum of square due to treatment were significant at $5 \%$ level for all the traits. The result showed that, the genotype Rudraprayag Local responded superior for number of pods per plant (21.10), yield of green pods per plant (249.92 g), yield of green pods per ha.(499.75 q/ha) and number of pickings (5.00). The genotype Anupam recorded best for plant height $(63.61 \mathrm{~cm})$, number of nodules per plant (14.5), fresh weight of nodules per plant $(150.27 \mathrm{mg})$ and the number of primary branches per plant (8.29). On the other hand, the average weight of the pod (13.52 g) was estimated in genotype Pant Anupama. Thus, it can be concluded that, the genotype Rudraprayag Local was recorded the best performer over check cultivar Contender with respect to yield parameters. Hence, the genotypes Rudraprayag Local could be recommended to enhance the production of french bean under subtropical condition of Garhwal Hills.
\end{abstract}

Analysis, Growth, Quality, Genotypes, Yield

\section{Introduction}

French bean (Phaseolus vulgaris L.) belonging to the family leguminaceae is also known by various names such as common bean, snap bean, green bean, kidney bean, haricot bean and dwarf bean (George, 1985). The primary center of origin is Southern Mexico and Central America while PeruvianEcuadorian- Bolivian area is the secondary centre of origin. It is originated from wild species Phaseolus aborigineus L. and domesticated in Mexico, Peru and Colombia about 8000 years ago. There are four cultivated species of Phaseolus, viz. P. vulgaris, $P$. coccineus, $P$. lunatus and $P$. acutifolius var. latifolius.

All the species are self-pollinated, except $P$. coccineus which is generally cross pollinated. Besides, adding atmospheric nitrogen with the help of symbiotic bacteria in the root nodules, 
it also adds considerable amount of organic matter in the form of sufficient foliage. The foliage of the crop also provides hay, silage and green manure. The development of new varieties is the long and expensive process which also need expert scientist especially, plant breeders. However, the evaluation of the existing and available french bean varieties for their adoption and productivity in the climatic condition of Garhwal hills is a faster way to improve french bean production. The french bean varieties selected for sowing by the farmers depends on several factors, which include production ability, regional adaptability and availability of seeds and their prices. The availability of seeds and the cost of seeds affect the adoption of the varieties by the farmer. If the seeds are expensive and difficult to obtain, the farmer find other available cheaper varieties in the local market which are usually of low productivity. Although several high yielding varieties and hybrids have been introduced during the last decades, there is a potential need for them to be evaluated in the agro-climatic condition of Garhwal. Most vegetable varieties trials including french bean focus on yield and quality attributes. The purpose of varieties evaluation trials was to identify promising french bean varieties and thus to provide upto-date variety recommendations for french bean growers.

\section{Materials and Methods}

The present experiment was conducted at Department of Horticulture, Horticulture Research Centre, Chauras H.N.B. Garhwal central University, Srinagar, Uttarakhand India, during summer season, 2017 titled, "Evaluation of French bean (Phaseolus vulgaris L.) genotypes for growth, pod yield and quality under sub-tropical condition of Garhwal Hills." The experiment was laid out in Randomized Block Design with three replications consisting 15 genotypes viz.,
Aishwarya, Anupam, Arka Komal, Durga Pencil Bean, Nirmala 101, Nitara Green, Pant Anupama, Pauri Local, Pencil 66, Rudraprayag Local, Shaguni, Srinagar Local, Somani, Selection-9 and Contender (Check cultivar). French bean seeds were sown in the field at a spacing of $45 \mathrm{~cm} \mathrm{x} 10 \mathrm{~cm}$ in plots of $2 \times 2 \mathrm{~m}$ size. During the investigation different growth, pod yield and quality parameters were recorded. The result of analysis of variance revealed that the mean sum of square due to treatment were significant at $5 \%$ level for all the traits.

The growth and yield parameters like, days taken to first germination, plant height $(\mathrm{cm})$, number of primary branches per plant, number of nodules per plant, fresh weight of nodules per plant $(\mathrm{g})$, dry weight of nodules per plant (mg), days taken to first flowering, days taken to first pod set, days taken to first pod picking, number of pods per plant, pod length $(\mathrm{cm})$, pod diameter $(\mathrm{cm})$, pod weight $(\mathrm{g})$, yield of green pods per plant $(\mathrm{g})$, yield of green pods per plot $(\mathrm{kg})$, yield of green pods per hectare $(\mathrm{q} / \mathrm{ha})$, number of picking and total soluble solid ( ${ }^{\circ}$ Brix) were recorded.

\section{Results and Discussion}

The representations of mean data of various growth, yield and quality characters of French bean genotypes in Table 1 and 2 are showing significant variations.

\section{Growth characters}

With respect to first seed germination the minimum (8.59 days) days was observed in Rudraprayag Local and the maximum (14.91 days) was noticed in Pauri Local. This may be due to the combine effect of soil temperature, moisture, texture and ability to germinate. The maximum $(63.61 \mathrm{~cm})$ plant height at harvest was recorded in Anupam showed superiority over check cultivar Contender 
$(52.04 \mathrm{~cm})$, whereas the minimum $(37.11 \mathrm{~cm})$ plant height at harvest was found in Somani. Basically plant height respond to several factors, like genetic constitution, adaptability, environmental condition, availability of nutrients and other management factors. The cumulative effect of these key factors showed in the form of plant height of crop. Similar results have also been reported by Anjanappa et al., (2000), Pawar et al., (2007), Rana and Kumar (2008), Das et al., (2014), Yadav (2015) and Das (2017) in french bean.

The maximum (8.29) number of primary branches per plant was recorded in genotype Anupam, whereas the minimum (3.71) number of primary branches per plant was recorded under the genotype Somani. The minimum (35.66 days) days taken to first flowering was recorded in genotype Arka Komal. On other hand the maximum (43.53 days) days taken to first flowering was recorded in the genotype Shaguni.

The maximum (14.59) number of nodules per plant was recorded in genotype Anupam while the minimum (7.78) was recorded under the genotype Somani. The number of nodules per plant is depends on the number of lateral root that in the plant and the nodulation is controlled by a variety of process, both external (heat, soil conditions, drought and nitrate) and internal factors (auto-regulation of nodulation and ethylene). These factors regulate the number of nodules per plant. The maximum (150.27 mg) fresh weight of nodules per plant was recorded in Anupam and minimum (75.05 $\mathrm{mg}$ ) fresh weight of nodules per plant was recorded in Somani. The fresh weight of nodules is directly correlated with the number of active nodules and their size. Dry weight of nodules per plant was recorded in Anupam which was found to be significantly superior over other genotypes, whereas the minimum (12.67 mg) dry weight of nodules per plant was observed in the Somani. The dry weight is directly correlated with the fresh weight and nodules size in crop. Similar observations have been reported by Muthal (2013) and Das (2017) in french bean.

\section{Yield and quality characters}

The minimum (40.85 days) days taken to first pod set was recorded in Pant Anupama, which was found to be significantly superior over other genotypes but statistically at par with Rudraprayag Local (41.22 days) and Arka Komal (41.96 days). On the other hand, maximum (49.46 days) days taken to first pod set was found in Shaguni. The minimum days (55.56 days) taken to first pod picking was recorded in Rudraprayag Local, followed by Pant Anupama (56.49 days) and Arka Komal (57.69 days), which was found to be significantly superior over other genotypes. On the other hand, the maximum (62.70 days) days taken to first pod picking was noticed in Pauri Local. The maximum number of pods per plant (21.10) was recorded in Rudraprayag Local, followed by Arka Komal (18.56) and Durga Pencil Bean (17.26), which was found to be significantly superior over the other genotypes, whereas minimum (9.66) number of pods per plant was found in Pauri Local. The maximum (13.52 g) average weight of the pod was recorded in Rudraprayag Local, which was found to be significantly superior over other genotypes but statistically at par with Arka Komal (12.78 g) and Pant Anupama (11.39), while the minimum $(7.61 \mathrm{~g}$ ) was found in Pauri Local. The maximum $(15.76 \mathrm{~cm})$ length of pod was observed in Rudraprayag Local which was found to be significantly superior over other genotypes but statistically at par with Pant Anupama $(15.71 \mathrm{~cm})$ and Arka Komal $(15.66 \mathrm{~cm})$. The minimum $(10.53 \mathrm{~cm})$ length of pod was found in Pencil 66. The maximum $(1.81 \mathrm{~cm})$ diameter of pod was recorded in Pant Anupama, which was found 
to be significantly superior over other genotypes but statistically at par with Rudraprayag Local $(1.73 \mathrm{~cm})$ and Arka Komal $(1.25 \mathrm{~cm})$. On the other hand, the minimum $(0.56 \mathrm{~cm})$ diameter of pod was found in genotype Nitara Green. Significantly maximum (5.00) number of pickings were observed in genotype Rudraprayag Local, followed by Pant Anupama (4.67) and Arka Komal (3.67), while the minimum (2.00) number of pickings were observed in Pencil 66 and Somani.

The maximum (249.92 g) yield of green pods per plant was recorded in the genotype Rudraprayag Local, followed by Arka Komal $(192.90 \mathrm{~g})$ and Pant Anupama (180.44 g), whereas the minimum yield of green pods per plant was observed in Pauri Local (91.68 g). The maximum $(19.99 \mathrm{~kg})$ yield of green pods per plot $(\mathrm{kg})$ was recorded in Rudraprayag Local, which was found to be significantly superior over other genotypes but statistically at par with Arka Komal (15.40 kg) and Nitara Green $(14.43 \mathrm{~kg})$, whereas the minimum $(7.33$ $\mathrm{kg}$ ) yield of green pods per plot $(\mathrm{kg})$ was found in Pauri Local. The maximum (499.75 $\mathrm{q} / \mathrm{ha}$ ) yield per hectare was recorded in Rudraprayag local, which was found to be significantly superior over other genotypes but statistically at par with Arka komal (385.08 q/ha) and Pant Anupama (360.75 $\mathrm{q} / \mathrm{ha}$ ). On the other hand, minimum (183.17 $\mathrm{q} / \mathrm{ha}$ ) yield was found in Pauri local. Yield is nothing but it is a cumulative effect of several factors like plant height, number of branches, pod length, pod diameter, pod weight.

Yield of green pod per hectare is directly correlated with the yield of green pods per plant and yield of green pods per plot. Singh et al., (2009) Patel et al., (2011), and Prakash and Ram (2014) reported similar findings in french bean.

Table.1 Mean performance of french bean genotypes for growth parameters

\begin{tabular}{|c|c|c|c|c|c|c|c|}
\hline Genotypes & $\begin{array}{l}\text { Days taken } \\
\text { to first } \\
\text { seed } \\
\text { germination }\end{array}$ & $\begin{array}{l}\text { Plant } \\
\text { height } \\
(\mathrm{cm})\end{array}$ & $\begin{array}{l}\text { No. of } \\
\text { primary } \\
\text { branch }\end{array}$ & $\begin{array}{c}\text { Days } \\
\text { taken to } \\
\text { first } \\
\text { flowering }\end{array}$ & $\begin{array}{l}\text { No. of } \\
\text { nodules } \\
\text { per plant }\end{array}$ & $\begin{array}{c}\text { Fresh weight } \\
\text { of nodules } \\
\text { per plant } \\
\text { (mg) }\end{array}$ & $\begin{array}{c}\text { Dry weight } \\
\text { of nodules } \\
\text { per plant } \\
\text { (mg) }\end{array}$ \\
\hline Aishwarya & 13.56 & 47.15 & 6.90 & 41.09 & 11.18 & 86.10 & 18.02 \\
\hline Anupam & 9.13 & 63.61 & 8.29 & 36.83 & 14.59 & 150.27 & 45.89 \\
\hline ArkaKomal & 11.03 & 54.59 & 7.41 & 35.66 & 13.68 & 144.30 & 42.54 \\
\hline $\begin{array}{l}\text { Durga Pencil } \\
\text { Bean }\end{array}$ & 11.91 & 49.06 & 5.22 & 39.88 & 12.17 & 131.75 & 35.11 \\
\hline Nirmala 101 & 13.24 & 46.92 & 6.57 & 40.03 & 11.87 & 81.10 & 15.40 \\
\hline Nitara Green & 13.98 & 40.25 & 4.89 & 38.86 & 12.14 & 120.67 & 34.42 \\
\hline Pant Anupama & 12.16 & 44.77 & 5.32 & 37.54 & 11.72 & 86.56 & 18.44 \\
\hline Pauri Local & 14.91 & 46.15 & 5.47 & 40.26 & 12.30 & 132.99 & 36.44 \\
\hline Pencil 66 & 11.58 & 53.07 & 6.58 & 39.33 & 10.74 & 80.82 & 15.40 \\
\hline $\begin{array}{l}\text { Rudraprayag } \\
\text { Local }\end{array}$ & 8.59 & 46.48 & 5.12 & 36.93 & 11.92 & 88.69 & 19.56 \\
\hline Shaguni & 13.40 & 44.27 & 6.19 & 43.53 & 12.14 & 129.46 & 34.25 \\
\hline Srinagar Local & 11.98 & 45.68 & 6.23 & 39.69 & 11.93 & 126.39 & 33.60 \\
\hline Somani & 12.13 & 37.11 & 3.71 & 40.18 & 7.78 & 75.05 & 12.67 \\
\hline Selection-9 & 11.54 & 49.87 & 5.40 & 39.65 & 12.78 & 134.71 & 41.69 \\
\hline $\begin{array}{l}\text { Contender } \\
\text { (Check) }\end{array}$ & 8.58 & 52.04 & 7.39 & 35.80 & 12.49 & 133.20 & 40.31 \\
\hline $\begin{array}{c}\text { S.Em } \pm \\
\text { CD at } 5 \%\end{array}$ & $\begin{array}{l}1.31 \\
3.81\end{array}$ & $\begin{array}{c}2.2 \\
5.84\end{array}$ & $\begin{array}{l}0.65 \\
1.89\end{array}$ & $\begin{array}{l}1.15 \\
3.34\end{array}$ & $\begin{array}{l}0.99 \\
2.85\end{array}$ & $\begin{array}{l}0.42 \\
1.22\end{array}$ & $\begin{array}{l}0.29 \\
0.85\end{array}$ \\
\hline
\end{tabular}


Table.2 Mean performance of french bean genotypes for yield and quality parameters

\begin{tabular}{|c|c|c|c|c|c|c|c|c|c|c|c|}
\hline Genotypes & $\begin{array}{c}\text { Days } \\
\text { taken } \\
\text { to first } \\
\text { pod } \\
\text { set }\end{array}$ & $\begin{array}{c}\text { Days } \\
\text { taken to } \\
\text { first pod } \\
\text { picking }\end{array}$ & $\begin{array}{l}\text { Number } \\
\text { of pods } \\
\text { per plant }\end{array}$ & $\begin{array}{c}\text { Pod } \\
\text { weight } \\
\text { (g) }\end{array}$ & $\begin{array}{c}\text { Pod } \\
\text { length } \\
(\mathrm{cm})\end{array}$ & $\begin{array}{c}\text { Pod } \\
\text { diameter } \\
(\mathbf{c m})\end{array}$ & $\begin{array}{l}\text { Yield of } \\
\text { green } \\
\text { pods per } \\
\text { plant (g) }\end{array}$ & $\begin{array}{l}\text { Yield of } \\
\text { green } \\
\text { pods per } \\
\text { plot }(k g)\end{array}$ & $\begin{array}{l}\text { Number } \\
\text { of picking }\end{array}$ & $\begin{array}{l}\text { Yield of } \\
\text { green } \\
\text { pod per } \\
\text { hectare } \\
\text { (q/ha) }\end{array}$ & $\begin{array}{c}\text { Total } \\
\text { soluble } \\
\text { solid } \\
\left({ }^{0} \text { Brix }\right)\end{array}$ \\
\hline Aishwarya & 46.32 & 58.18 & 15.97 & 9.35 & 13.32 & 0.63 & 149.79 & 11.98 & 3.00 & 299.42 & 5.53 \\
\hline Anupam & 42.57 & 60.91 & 12.12 & 11.29 & 15.62 & 1.06 & 101.42 & 8.11 & 3.33 & 202.75 & 6.50 \\
\hline ArkaKomal & 41.96 & 57.69 & 18.56 & 12.78 & 15.66 & 1.25 & 192.90 & 15.40 & 3.67 & 385.08 & 7.02 \\
\hline Durga Pencil Bean & 46.49 & 58.64 & 17.26 & 9.97 & 12.62 & 1.04 & 173.13 & 13.85 & 2.33 & 346.17 & 5.57 \\
\hline Nirmala 101 & 47.48 & 61.64 & 11.22 & 10.32 & 15.13 & 0.88 & 100.72 & 8.05 & 3.00 & 201.25 & 5.06 \\
\hline Nitara Green & 44.41 & 57.86 & 14.03 & 8.66 & 15.46 & 0.56 & 107.27 & 8.58 & 3.00 & 214.42 & 5.73 \\
\hline Pant Anupama & 40.85 & 56.49 & 13.31 & 11.39 & 15.71 & 1.81 & 180.44 & 14.43 & 4.67 & 360.75 & 6.60 \\
\hline Pauri Local & 47.64 & 62.70 & 9.66 & 7.61 & 11.15 & 1.07 & 91.68 & 7.33 & 2.33 & 183.17 & 5.64 \\
\hline Pencil 66 & 45.83 & 59.02 & 10.01 & 10.87 & 10.53 & 1.13 & 109.18 & 8.73 & 2.00 & 218.25 & 5.20 \\
\hline Rudraprayag Local & 41.22 & 55.56 & 21.10 & 13.52 & 15.76 & 1.73 & 249.92 & 19.99 & 5.00 & 499.75 & 5.59 \\
\hline Shaguni & 49.46 & 58.72 & 17.09 & 8.23 & 14.19 & 1.04 & 160.30 & 12.82 & 3.00 & 320.50 & 5.51 \\
\hline Srinagar Local & 44.53 & 57.71 & 16.52 & 8.42 & 13.50 & 0.76 & 168.87 & 13.51 & 3.33 & 338.17 & 5.58 \\
\hline Somani & 48.34 & 58.03 & 15.63 & 8.40 & 12.32 & 1.03 & 179.62 & 14.37 & 2.00 & 359.17 & 5.30 \\
\hline Selection-9 & 46.97 & 60.20 & 14.54 & 10.34 & 12.03 & 1.23 & 165.88 & 13.27 & 3.33 & 331.67 & 5.44 \\
\hline Contender (Check) & 40.36 & 55.83 & 19.59 & 13.31 & 15.59 & 1.33 & 208.33 & 16.66 & 3.33 & 416.58 & 6.65 \\
\hline S.Em \pm & 0.67 & 0.42 & 0.58 & 0.95 & 1.02 & 0.14 & 17.32 & 1.39 & 0.33 & 34.66 & 0.29 \\
\hline CD at $5 \%$ & 1.95 & 1.21 & 1.69 & 2.76 & 3.98 & 0.40 & 50.17 & 4.02 & 0.96 & 100.41 & 0.83 \\
\hline
\end{tabular}


Maximum (7.02 ${ }^{0}$ Brix) total soluble solid was recorded in Arka komal, which was found to be significantly superior over other genotypes but statistically at par with Pant Anupama (6.60 ${ }^{0}$ Brix) and Anupam (6.50 ${ }^{0}$ Brix), whereas the minimum $\left(5.06{ }^{0} \mathrm{Brix}\right)$ total soluble solid was found in Nirmala 101. The similar findings were reported by Sarangi and De (2010) in French bean and Bhutia et al., (2017) in Pea.

On the basis of results obtained from the present investigation, it may be concluded that, the genotype Rudraprayag Local recorded best performer over check cultivar Contender with respect to yield parameters. Hence, the genotypes Rudraprayag Local could be recommended to enhance the production of french bean under subtropical condition of Garhwal Hills.

\section{References}

Anjanappa M, Reddy NS, Krishnappa KS, Murali K and Pitchaimuthu M. 2000. Performance of french bean varieties under southern dry region of Karnataka. Karnataka Journal of Agriculture Science, 13(2): 503-505.

Bhutia TL, Shivani and Saurabh K. 2017. Evaluation of different varieties of pea (Pisum sativum L.) for yield and quality under late sown conditions in Eastern region. Crop Research, 52 (4 \& 5): 176179 .

Das K. 2017. Varietal performance of bush type french bean varieties (Phaseolus vulgaris L.) for growth, fresh pod yield and quality. M. Sc Thesis. Uttar Banga Krishi Viswavidyalaya, Pundibari, Cooch Behar, West Bengal, India

Das R, Thapa U, Debnath S, Lyngdoh YA and Mallick D. 2014. Evaluation of french bean (Phaseolus vulgaris L.) genotypes for seed production. Journal of Applied and Natural Science, 6(2):
$594-598$

George RAT. 1985. Vegetable Seed Production. Longman, London \& New York, pp:193- 207.

Muthal KM. 2013. Evaluation of french bean (Phaseolus vulgaris L.) varieties for Northern dry-zone of Karnataka. M.Sc. Thesis. University of Horticultural Sciences, Bagalkot.

Patel BV, Parmar BR, Parmar SB and Patel SR. 2011. Effect of different spacings and varieties on yield parameters of cowpea (Vigna unguiculata L.). The Asian Journal of Horticulture, 6(1): 5659.

Pawar SU, Kharwade ML and Awari HW. 2007. Effect of plant density on vegetative growth and yield performance of different varieties of french bean under irrigated condition. Karnataka Journal of Agricultural Science, 20(3): 684-685.

Prakash J and Ram RB. 2014. Genetic variability, correlation and path analysis for seed yield and yield related traits in french bean (Phaseolus vulgaris L.) under Lucknow conditions. International Journal of Innovative Science, Engineering and Technology. 1(6): 41-50.

Rana DK and Kumar A. 2008. Performance of various french bean (Phaseolus vulgaris L.) genotypes under mid-hill condition of Garhwal Himalaya. Progressive Horticulture, 40(2): 184186.

Sarangi SK and De LC. 2010. Varietal evaluation of french bean (Phaseolus vulgaris L.) at mid-hills of Arunachal Pradesh. Indian Journal of Hill Farming, 23(2): 53-54.

Singh AK, Singh SB and Singh V. 2009. Influence of nitrogen doses on growth and green pod yield parameters of french bean varieties during kharif season under subtropical area of Jammu 
region. Legume Research, 32(2): 142144.

Yadav BVS. 2015. Performance of vegetable french bean (Phaseolus vulgaris L.) as influenced by varieties and sowing dates under Southern Zone of Andhra Pradesh. M.Sc. Thesis. Dr. Y. S. R. Agricultural University, Y. S. R. District, Andhra Pradesh.

\section{How to cite this article:}

Hema and Rana. D. K. 2020. Evaluation of French Bean (Phaseolus vulgaris L.) Genotypes for Growth, Pod Yield and Quality under Sub-Tropical Condition of Garhwal Hills. Int.J.Curr.Microbiol.App.Sci. 9(07): 974-980. doi: https://doi.org/10.20546/ijcmas.2020.907.114 